\title{
Digitalizing Historical Documents in the Current Disruptive Industrial Era
}

\author{
Karta Jayadi", Muhammad Agung ${ }^{\#}$, Amirullah Abduh ${ }^{\# *}$, Andi Anto Patak ${ }^{\#}$

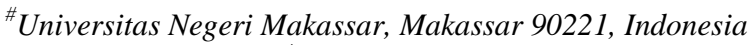 \\ E-mail: "amirullah@unm.ac.id
}

\begin{abstract}
Since not many studies conducted in the area of digitalization of historical documents, this study is undoubtedly significant to carry out. Specifically, this study explores the importance and the benefits of digitalizing historical documents. The ethnographic research uses questionnaires and interviews for data collection. The questionnaire items are made available digitally so that participants in this study can complete and submit to the researchers digitally. The questionnaire items are analyzed digitally using google drive software and the interviews are analyzed qualitatively to triangulate data from the questionnaires. The participants of the study included 40 respondents who are both art observers and academics. The researchers choose participants purposively because of their knowledge, their involvement in the digitalization, and their experiences in the historical documents. The result of the study shows that various perspectives appear from participants in the relation of the importance of digitalizing historical documents. More importantly, the digitalization can be a benefit for artists, academics, art observers, art lovers, and the public art community. Digitalization of historical documents can be useful for teaching and learning, research purposes, document history of civilization, marketing, socialization, portray of artists and prediction of the future of the civilization. This study implies that this research can be a model for exploring the digitalization of historical documents in a similar geographical setting worldwide.
\end{abstract}

Keywords — historical documents; digitalization; disruptive industrial era.

\section{INTRODUCTION}

Currently, there is increasing attention in the use of digitalization across the globe. Many investigations conducted in the digitalization of anthropology of art are conducted in western research tradition. Consequently, minimal information and publication found globally relates to the digitalization of anthropology of arts in Indonesia. This study can be claimed as the pioneer study in the digitalization of anthropology of arts within the Indonesian context. This study contributes to the debate and the development of arts, artwork and anthropological arts around the world.

Industrial revolution refers to the transformation of industrial manufacturing, including the work of arts through digitalization and manifestation of prospects of the most updated technologies [1]. Besides, the industrial revolution 4.0 refers to the concepts based on cyber-physical production systems by merging real-life contexts and virtual worlds [2]. It can be inferred that the transformation of reallife anthropology of arts into virtual worlds can be described as the form of digitalization of anthropology of arts.

Research on the digitalization of anthropology of art has been conducted in many areas worldwide. The study focuses on micro-perspectives on rationality and creativity in Arts and Anthropology [3]. The other investigations are the contemporary perspectives of digital arts and anthropology [4], the importance of digital anthropology of arts [5], the questioning of the effective channel for digitalizing anthropology of art [6], and the benefits and challenges of digitalization and open access in the area of anthropology of art [7].

Some studies have focused on the benefit of the digitalization of historical documents such as anthropology of arts in the digital disruptive industrial era. A scholar has described the overview and the concept of disruptive industrial revolution 4.0 era as a new digital mechanism where people can share their ideas, socialize and publish their unique contribution to the world [1]. Previous studies have explored hybrid e-learning in the 4.0 industrial revolution [8]. Therefore, the disruptive industrial revolution is a new technological space where people create new ideas and produces the result of the concepts that can be accessed publically by people around the world. This research is no doubt significant for the development and sustainability of anthropology of art within the Indonesian context. This type of study can be a model for understanding the digitalization of anthropological art. 


\section{MATERIALS AND METHODS}

\section{A. Materials and instruments}

There are three main instruments for this study: participant observations, questionnaires, and interviews. However, for this article, only questionnaire and interview results are depicted and discussed here in this paper. All questionnaire items have been tested in advance to the check validity and reliability of the questionnaire elements and the interview questions have been pre-tested to the artists for clarity of the question contents. This mechanism is conducted to ensure the credibility of the research ( [9].

\section{B. The procedure of data collection}

There are several procedures for collecting data in this research. This study follows the suggestion of social research scholars [10] in data collection: identifying key persons to send questionnaires, pretesting questionnaire to the art observers and artists, and interviewing them. Once they agree to participate, the principal researcher sends the link of the questionnaire placed in digital google drive. Consequently, participants in this study can easily access the research questionnaire items. The questionnaires were sent to all departments of arts in Indonesia especially those who are experts and observers in the area of historical documents such as the anthropology of arts. The researchers sent to 60 participants; however, more than $50 \%$ of the participants filled the questionnaire and answered digital interview questions. All the participants are code with participant one (P1), participant two (P2) consecutively.

\section{Methods}

This study uses ethnographic research design. This ethnographic research design is appropriate because it the principal researcher in this study has visited many places and has observed for more than a year in the development of the Anthropology of art in the digital media. The ethnographic study relates to the in-depth investigation of the phenomena or the cultural elements of a certain community for a longer period [11]. This study takes place for more than a year.

\section{RESULTS AND DISCUSSION}

\section{A. Results}

All data in the questionnaire items are analyzed quantitatively via digital google drive space. The procedures of analysis [12] are that all the data are recorded digitally, they are coded electronically, and the data are transferred into Ms word for writing up the result.

1) The profile of the participants of the study:

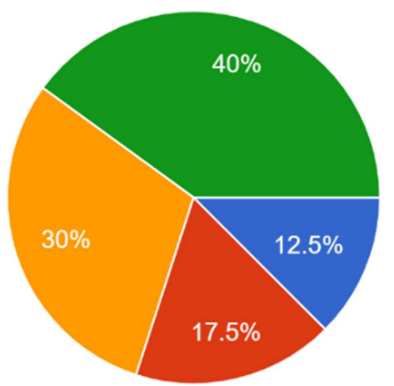

Fig. 1 Age ranges of the participants in this study
Figure 1 above indicating the participants of the study nearly half of them age over $50 \mathrm{~s}$, a quarter of them age $40 \mathrm{~s}$, and the rest is age 30s and 20s. This shows that participants in this study have a long experience as artists and teachers of arts. Most of them are female and the rest is male artists.

2) The occupation of the participants:

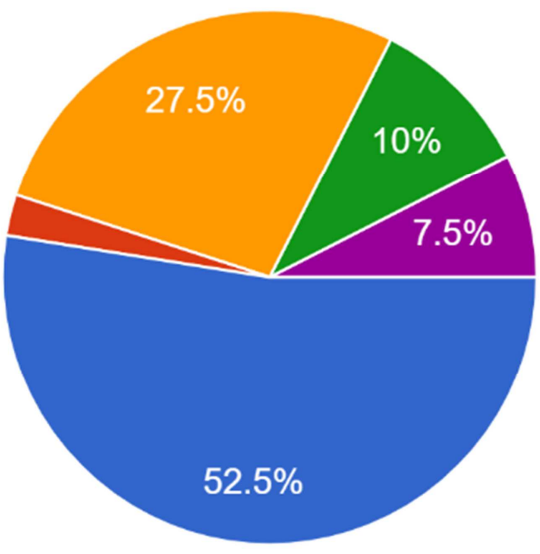

Fig. 2 Participants occupation

Figure 2 describing most of the participants in the study who are fine artists following performance arts, musical arts, and painting arts. The only very small number of the participants are the mixed professions. Among those participants, more than half of them are art observers and artists. Besides, half of the number of participants are anthropology of art observers and actors.

3) The significance of digitalizing historical documents: It is interesting to note that that most of the participants agree that historical documents such as art and anthropology of arts as one of the most important fields that contribute positively to the development of arts in general. Most participants indicate in Figure below:

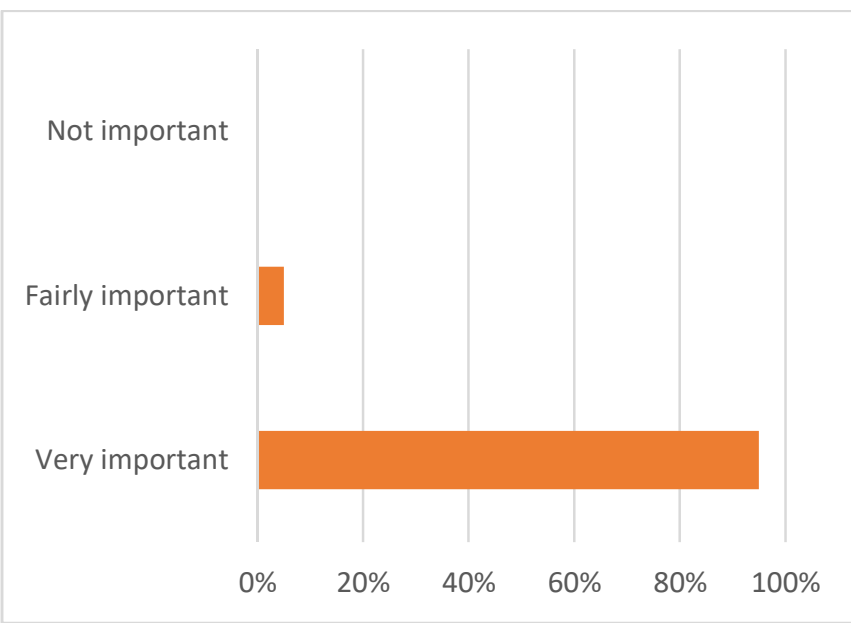

Fig. 3 The significance of digitalizing historical documents

Figure 3 portraying participants in this study have various reasons why historical documents such as anthropology of art is significant and beneficial for the development of art in general and anthropology of art. The first reason is art and 
anthropology as approaches and methods for art learning and art creation. More detail of the reasons is in Table 1 below:

\section{TABLE I}

DIGITALIZING AS A FORM OF A METHODOLOGICAL APPROACH

\begin{tabular}{|c|c|}
\hline Participants & Perspectives on the Anthropology of Arts \\
\hline $\mathrm{P} 1$ & $\begin{array}{l}\text { It is very useful because the works of art are } \\
\text { dominant using the anthropological approach }\end{array}$ \\
\hline $\mathrm{P} 2$ & $\begin{array}{l}\text { Because by studying art anthropology, it can be } \\
\text { understood symbols and artistic identities based } \\
\text { on location and region. }\end{array}$ \\
\hline P3 & $\begin{array}{l}\text { Anthropology in the scientific field of art is a } \\
\text { bridge to unravel and earth between humans and } \\
\text { the results of their work as a form of } \\
\text { implementation of mind-words-deeds in their } \\
\text { community. }\end{array}$ \\
\hline $\mathrm{P} 4$ & $\begin{array}{l}\text { Yes, because it will be examined using } \\
\text { anthropological methods }\end{array}$ \\
\hline P5 & It is self-teaching of art theoretically \\
\hline P7 & It can be a basis/concept in creating art \\
\hline P10 & $\begin{array}{l}\text { Useful for art scientific studies as one of the } \\
\text { approaches and paradigms }\end{array}$ \\
\hline
\end{tabular}

Table 1 indicates participants' comments that the digitalization of anthropology of arts provides the basis for a new form of investigation through the combination of arts and the virtual world. The study of digitalization can produce a new form of identity that symbolizes the region and community. Also, the digitalization of anthropology of art can bridge the human works and virtual technological form. The second reason for digitalizing art and anthropology of art is to describe the culture and identities of community and artists.

TABLE II

PARTICIPANTS' VOICES ON HISTORICAL ART AS IDENTITY

\begin{tabular}{|c|c|}
\hline Participants & Perspectives on the Anthropology of Arts \\
\hline $\mathrm{P} 11$ & $\begin{array}{l}\text { Yes, because an artist needs a lot of inspiration } \\
\text { and that is a lot to be found in the field of art } \\
\text { anthropology, especially for artists who love } \\
\text { culture will surely include anthropological } \\
\text { elements in his work }\end{array}$ \\
\hline $\mathrm{P} 15$ & $\begin{array}{l}\text { Because the study of art anthropology examines } \\
\text { humans, culture and art comprehensively using } \\
\text { interdisciplinary theories so that it can contribute } \\
\text { to the production of scientific knowledge of art } \\
\text { and inspiration to the production of artistic } \\
\text { creativity }\end{array}$ \\
\hline P16 & $\begin{array}{l}\text { It is full of value, meaning, not quantity but } \\
\text { quality; its position is in the area of culture. } \\
\text { Because humans are the rulers in the creative } \\
\text { process }\end{array}$ \\
\hline P18 & $\begin{array}{l}\text { The history of the long journey of mankind in the } \\
\text { world must have spawned his midnight culture in } \\
\text { Egypt with the discovery of the letter hierogram } \\
\text { or cuneiform writing that could inspire the birth } \\
\text { of art }\end{array}$ \\
\hline $\mathrm{P} 20$ & $\begin{array}{l}\text { By studying the science of anthropology that is } \\
\text { developing in a culture or local community, it is } \\
\text { undoubtedly very inspiring for the birth of more } \\
\text { advanced and dignified works of art. }\end{array}$ \\
\hline P22 & All nations of the world give birth to culture. \\
\hline P28 & $\begin{array}{l}\text { Yes ... Because of the close relationship between } \\
\text { art practitioners about the anthropology of art to } \\
\text { create the birth of art in terms of culture, } \\
\text { behavior, and character of its creators. Because } \\
\text { art anthropology can be used as an approach in }\end{array}$ \\
\hline
\end{tabular}

\begin{tabular}{|l|l|}
\hline & $\begin{array}{l}\text { studying or dissecting artworks/products and } \\
\text { indeed artwork is also a cultural product }\end{array}$ \\
\hline P30 & $\begin{array}{l}\text { because in creating many dance themes are } \\
\text { inspired by certain community activities or } \\
\text { culture }\end{array}$ \\
\hline
\end{tabular}

Table 2 above describes the participants' voice that indicates the digitalization represent communities and uniqueness in the virtual world. This provides new domains and spaces for people to be more creative since they are the planners of art activities happening both in the real and virtual worlds. It creates the form of other cultures, and it can be categorized as the form of third or fourth culture. The third reason is that it provides portraits of the aesthetic values of art and anthropology of art. Participants indicate their comments on the digitalizing arts as aesthetic values (Table 3) below:

TABLE III

Digitalizing Historical Documents As Aesthetic Values

\begin{tabular}{|c|l|}
\hline Participants & Perspectives on the Anthropology of Arts \\
\hline P6 & $\begin{array}{l}\text { Measuring the value of a meaning contained in } \\
\text { the form of objects that have meaning through } \\
\text { the aesthetic form }\end{array}$ \\
\hline P19 & $\begin{array}{l}\text { Because anthropology has a close relationship } \\
\text { with art which has an internal element in a } \\
\text { tradition as aesthetic values }\end{array}$ \\
\hline $\begin{array}{l}\text { Anthropology of art is a science that studies } \\
\text { and studies about humans and their culture, } \\
\text { culture here is defined as a visual culture that } \\
\text { presents visual works that can be interpreted } \\
\text { visually with the presentation of aesthetic } \\
\text { values in it. Visual works have evolved from } \\
\text { time to time. Starting from the media, } \\
\text { techniques to enter the flow or also called } \\
\text { cultural transformation. Of course, we need to } \\
\text { study various types of works of art because it } \\
\text { does not rule out the possibility if we can make } \\
\text { something new and different from the types of } \\
\text { art that already exist. }\end{array}$ \\
\hline P27 & $\begin{array}{l}\text { It is very important because in art there are } \\
\text { aesthetic values in community traditions. }\end{array}$ \\
\hline
\end{tabular}

Table 3 above indicates that the digitalization of historical documents such as anthropology of arts can be portrayed as forms of aesthetic activities because the merger of real-world production into virtual space requires special techniques and artistic process - for example, the choice specific domain, layout and the physical appearance of the online arts. Also, the digitalization of anthropology of art is a form of visual culture that presents aesthetic values beginning from the transformation, media and the flow of arts.

The last reason is that historical documents such as art and anthropology of arts provide an opportunity the study of the development of communities and avoid extinction of the culture of the community. Participants indicate their comments on digitalizing arts to avoid extinction (Table 4). Table 4 above reveals that the digitalization of historical documents such as anthropology of arts provides new insight for academic and scientific communities to be explored and further investigated. The anthropology of arts is digitalized can develop the appreciation and stimulate the more creative work in real life. This is also a form of the ontology of life 
that describes the beginning of human lives that are portrayed in the arts, then they are transformed into digital or virtual reality.

TABLE IV

AVOIDING EXTINCTION

\begin{tabular}{|c|c|}
\hline Participants & $\begin{array}{l}\text { Perspectives on the importance of } \\
\text { digitalizing art and anthropology of art }\end{array}$ \\
\hline P8 & As a study for giving birth to art \\
\hline P9 & $\begin{array}{l}\text { Knowing the background of the arts } \\
\text { supporting community will help to } \\
\text { appreciate the art more easily }\end{array}$ \\
\hline P12 & $\begin{array}{l}\text { Yes, it is very useful especially since we can } \\
\text { learn from the study }\end{array}$ \\
\hline P13 & $\begin{array}{l}\text { Humans, arts and anthropology are two } \\
\text { interrelated things that influence one another }\end{array}$ \\
\hline P14 & $\begin{array}{l}\text { Anthropology of art provides an } \\
\text { understanding of various aspects of human } \\
\text { life and its relation to the birth of art that is } \\
\text { an anthology that describes aspects of life }\end{array}$ \\
\hline P17 & $\begin{array}{l}\text { Because anthropology is closely related to } \\
\text { the birth of art }\end{array}$ \\
\hline $\mathrm{P} 21$ & $\begin{array}{l}\text { The locality is the inspiration for the creation } \\
\text { of work as a symbol of representation both } \\
\text { ideas and the locality of the work }\end{array}$ \\
\hline $\mathrm{P} 23$ & It gives a theoretical understanding \\
\hline $\mathrm{P} 25$ & $\begin{array}{l}\text { Anthropology studies provide information } \\
\text { that can be ideas/inspiration for artists to be } \\
\text { more creative in creating \& responsible for } \\
\text { the artwork produced }\end{array}$ \\
\hline P26 & $\begin{array}{l}\text { To understand the overall development of art } \\
\text { from prehistoric times to modern times }\end{array}$ \\
\hline P29 & $\begin{array}{l}\text { Art anthropology enriches the atmosphere } \\
\text { and scientific insights about the phenomenon } \\
\text { of art as a whole }\end{array}$ \\
\hline P31 & $\begin{array}{l}\text { The artwork is something that lives and } \\
\text { develops. The characteristic marks that } \\
\text { artworks are still needed; and because it is } \\
\text { needed it can transform, adapt and even be } \\
\text { assimilated in every form, style, model, even } \\
\text { the era in which humans are engaged in. For } \\
\text { me, the study of anthropology is important } \\
\text { as a root nurse, along with all the symptoms } \\
\text { and facts of the growth of art itself }\end{array}$ \\
\hline
\end{tabular}

Table 4 above reveals that the digitalization historical documents such as anthropology of arts provides new insight for the academic and scientific community to be explored and further investigated. The anthropology of arts is digitalized can develop the appreciation and stimulate the more creative work and collaboration [13] in real life. This is also a form of the ontology of life that describes the beginning of human lives that are portrayed in the arts; then, they are transformed into digital or virtual reality.

4) The advantages of digitalizing the historical documents: there are many advantages why anthropology of art is essential to digitalize. For example, it is crucial for archiving art and anthropology of art digitally. Participants in this study indicate the usefulness of digitalizing the anthropology of arts.

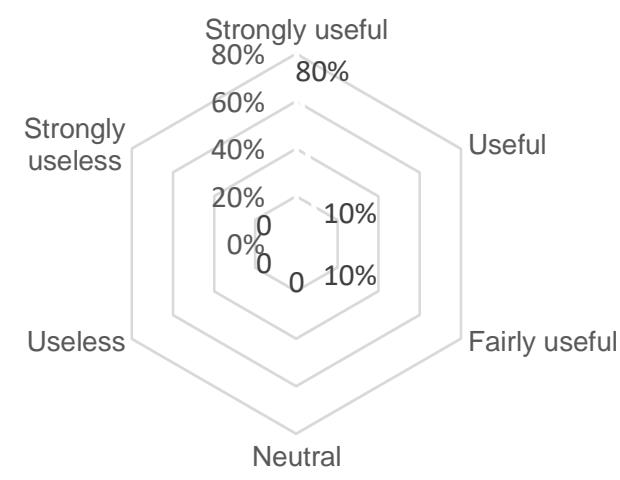

Strongly useful
Fairly useful
Useless

Useful

Neutral

Strongly useless

Fig. 4 The usefulness of digitalizing historical documents

Figure 4 above shows that most participants in this study believe that digitalizing historical documents such as the anthropology of arts can benefit communities and artists. It can be from Figure 5 that $80 \%$ of the participants strongly agree on digitalizing because it can provide benefits for the community. This figure means that the digitalization of anthropology of art can provide new perspectives and new ways of understanding arts and development especially in the current development era. This figure indicates that the digitalization of anthropology of art is essential for artists and art communities since many of the previous art products cannot be traced to their existence. No participants in this study believe that anthropology of arts cannot be digitalized.

\section{B. Discussion}

From participants' comments, there are six advantages of digitalization of historical documents such as anthropological art, as stated in Figure 6 below:

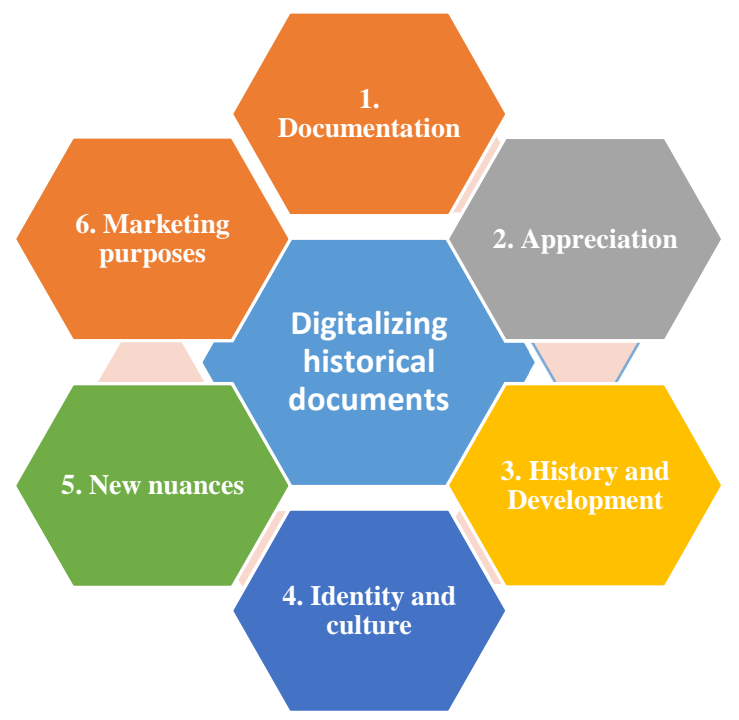

Fig. 5 Model of digitalizing historical documents

Figure 5 above shows the advantages of digitalizing historical documents such as the anthropology of arts. Firstly, it is a form of documentation. Participants indicate 
that:" it is time for art and anthropological studies to be digitally documented" (P1). Also, "digitalization is a method of standardizing repositories in the form of documents of works of human creations and initiatives based on their 'need' and 'will" (P2). It is also "following the era and takes advantage of digital advantages in inventorying/documenting the results of studies and to disseminate them" (P12). This indicates that artwork and/or anthropological studies need to be digitalized in the revival era of the industrial revolution 4.0 because of the digitalization of works related to documentation and production publications. Besides, it is the era of technology that demands flexibility from various viewpoints of science to influence the process of transfer of technology-based media is no exception art.

Second, Figure 5 indicates that it is a form of art appreciation. Participants comment that "part of the modern era that is completely digital as a vehicle or media that can refer to the revitalization of a monumental work that is important to be used as a reference later in the future some means of appreciation" (P4). Also, "the development of the world of art must be in contact with IT so that the work of digitalization is to appreciate the material forms of arts" (P22). Therefore, people appreciate it through digitalization because the era is now an era that uses sophisticated technology.

Third, in Figure 5, it is to trace art history and development. Participants believe that: "the more rapid development of digitalization, the work of art needs to follow and so that a new ism will emerge in the special works of art, but the manualization of art still has its own value that is timeless" (P5). Besides, other participants add that "to preserve the study of art anthropology there is a need for digitalization especially in modern times. It also provides digital traces in this study" (P9). The digitalization program system can be software for the development of art analogy and it will help of digitization can create a cultural journey map of a nation. Furthermore, it is necessary because it can accelerate the process of reconstructing a cultural journey through digitalization and make it easier to spread information, for learning now and in the future.

Fourth, in Figure 5, the digitalization of historical documents such as anthropology of arts helps for marketing purposes. Participants argue that: "it works to be distributed to the free market (consumers) through various fast and sophisticated technological media that can produce financially" (P14) and it is to "make art or anthropological studies more easily managed, produced, distributed, published, more importantly, marketed in a long period" (P19). More importantly, by digitalization, it can make the arts to "be easily accessible for the public" (P27). The artwork is a necessity for digitalization because it is a public possession and it aims for public exhibition.

Fifth, in Figure 5, it provides new nuances for historical documents such as anthropology of arts. Participants state "of the current era of digital science, it offers new perspectives" (P3), and "artwork continues to grow in line with the changing times including the presence of the digital era which gives a new nuance to the work" (P6). Besides, the digitization of works of art can be used as a strategic step to advance Indonesian art in a digital era so that art can go with the times, new issues and new understanding of arts.

Figure 5 also shows that digitalization aims to preserve cultures and art management. Participants indicate that "times are increasingly developing and sophisticated, it is better to create, build, change, preserve and even develop the solid in the language of certain symbols digitally" (P15). With the digitalization, "it will help the community's understanding of and related issues including art anthropology and it is a form of cultural maintenance" (P30). The anthropology of arts can portray identities of communities and identity of speakers [14], can be in the form of identity maintenance, and can be in the form of digital identity. More importantly, it expands the broader creative space ([15] for artists and art observers.

All participant agrees that digitalizing historical documents such as the anthropology of art is actively beneficial for sustainability and development of artwork in the future. The implication of this study is that:

- There are many artists and community artists who would digitalize their works and provides a new lens for their works.

- The digitalization of artworks can help trace the critical segment of the Anthropology of Arts.

- The digitalization of historical documents such as anthropology of arts can be a form of new perspectives in understanding arts and researching arts and anthropology of arts.

From the findings above, the digitalization of historical documents such as anthropology of arts can be described as the new form of social innovation[16]. The new social innovation is the newer form of interaction between technology and human beings that aim to bring about sustainable and practical living in the modern world.

\section{IV.CONCLUSION}

The result of the study shows that various perspectives appear from participants in the relation of the importance of digitalizing historical documents such as anthropology of arts. More importantly, the digitalization of historical documents such as anthropology of art can be a benefit for artists, academics, art observers, art lovers, and the public art community. The figure below provides perspectives and concepts in digitalizing historical documents like art and anthropology of art.

Digitalization of historical documents such as anthropology of arts can be useful for teaching and learning, research purposes, document history of civilization, marketing, socialization, portray of artists and prediction of the future of the civilization. This study implies that this research can be a model for exploring the digitalization of historical documents such as anthropology of art in a similar geographical setting worldwide.

\section{ACKNOWLEDGMENT}

This research article is based on the research grant of Universitas Negeri Makassar, Indonesia, with the contract number: 736/UN36.9/PL/2018. We thank the Rector of Universitas Negeri Makassar for the research grant. For 
comments and questions, please email the corresponding author, Amirullah Abduh: amirullah@unm.ac.id.

\section{REFERENCES}

[1] A. Rojko, "Industry 4 . 0 Concept: Background and Overview," iJIM, vol. 11, no. 5, pp. 77-90, 2017.

[2] R. C. Schlaepfer and M. Koch, Challenges and solutions for the digital transformation and use of exponential technologies. Switzerland: Coorporate Finance, 2019.

[3] R. Blanes, A. Flynn, M. Maskens, and J. Tinius, "Micro-utopias: anthropological perspectives on art, relationality, and creativity.," vol. 5, no. 1, pp. 5-20, 2019.

[4] P. Budka and A. Escobar, "From Cyber to Digital Anthropology to an Anthropology of the Contemporary ?," no. December, pp. 1-15, 2011.

[5] D. Miller, "Digital Anthropology," in The Cambridge Encyclopedia of Antrhopology, F. Stein, S. Lazar, M. Candea, H. Diemberger, J. Robbins, A. Sanchez, and R. Stasch, Eds. London: Cambridge University Press, 2018, pp. 1-16.

[6] H. A. Horst, D. Miller, and T. Boellstorff, digital anthropology. London and New York: Bloomsbury Berg Publishers, 2012.

[7] D. M. Iller, "Open access, scholarship , and digital anthropology," vol. 2, no. 1, pp. 385-411, 2012.
[8] H. Syam, M. Basri, A. Abduh, and A. A. Patak, "Hybrid e-Learning in Industrial Revolution 4 . 0 for Indonesia Higher Education," Int. J. Adv. Sci. Eng. Inf. Technol., vol. 9, no. 4, pp. 1183-1189, 2019.

[9] N. Blaikie and J. Priest, Designing social research: The logic of anticipation. John Wiley \& Sons, 2019.

[10] R. Kumar, Research methodology: A step-by-step guide for beginners. Sage Publications Limited, 2019.

[11] M. Gall, J. Gall, and W. Borg, Educational research: an introduction. Boston: Pearson/ Allyn \& Bacon, 2007.

[12] C. Quinlan, B. Babin, J. Carr, and M. Griffin, Business research methods. South Western Cengage, 2019.

[13] R. Rosmaladewi and A. Abduh, "Collaborative Teaching Cultures of English Lecturers in Indonesian Polytechnics," Int. J. Lang. Educ., vol. 01 , no. 01 , pp. 20-28, 2017.

[14] A. Abduh and R. Rosmaladewi, "Language policy, identity, and bilingual education in Indonesia: a historical overview," XLinguae, vol. 12, no. 219-227, 2019.

[15] J. Cui, "Research on Digital Painting Art and Its Diversified Performance," in 3rd International Conference on Economics, Social Science, Arts, Education and Management Engineering, 2017, vol. 119 , no. 1, pp. 1429-1432.

[16] R. Morrar, H. Arman, S. Mousa, and K. Schwab, "The Fourth Industrial Revolution ( Industry 4 . 0 ): A Social Innovation Perspective," Technol. Innov. Manag. Rev., vol. 7, no. 11, pp. 12-21, 2017. 